Нижегородский государственный университет им. Н.И. Лобачевского, 2010. - 96 с. [Электронный peсурс]. - Режим доступа: http:/www.unn.ru/books/met_files/ LevinaLM.pdf. 6. Основы критического мышления: междисциплинарная программа /Дж. Стил, К. Мередит, Ч. Темпл, С. Уолтер. Пособие 1. - М. : Изд -во «ИОО», 1997. - 213 с. 7. Развитие критического мышления средствами ИКТ. [Электронный pecypc]. - Режим доступа: https://sites.google.com/site/mkiktkm/ vizualnye-organizatory. 8. Сиземина А. Е. Стратегия применения графических организаторов при обучении лексической стороне иноязычной речи / Александра Евгеньевна Сиземина. - [Електронний ресурс]. - Режим доступу: http://vernadsky.tstu.ru/pdf/2009/06/rus_07_2009_06.pdf 9. Халперн Д. Психологія критичного мислення / Дайана Халперн. - [Електронний ресурс]. - Режим доступу: http://lib.rus.ec/b/214789/read. 10. Hall T. (2002). Graphic organizers. Wakefield, MA: National Center on Accessing the General Curriculum./ T. Hall, N. Strangman.[Електронний ресурс].- Режим доступу: http://aim.cast.org/learn/historyarchive/backg roundpapers/graphic_organi.

УДК 378.147

Артем Сушенцев

\title{
РЕАЛІЗАЦІЯ ПРИНЦИПІВ ПРОФЕСІЙНОГО ВДОСКОНАЛЕННЯ ВИРОБНИЧОГО ПЕРСОНАЛУ В УКРАЇНІ
}

Сушенцев А. О. Реалізація принципів професійного вдосконалення виробничого персоналу в Україні.

У статті досліджені принципи професійного вдосконалення 3 точки зору провідних науковців. Проаналізовані такі принципи професійного вдосконалення виробничого персоналу, як: політехнічний принцип, принцип моделювання професійної діяльності в навчальному процесі, принцип професійної мобільності, принцип модульності тощо.

Ключові слова: принцип навчання, партисипативність, синергія, безперервне професійне навчання, вдосконалення персоналу.

Сушенцев А. А. Реализация принципов профессионального совершенствования производственного персонала в Украине.

В статье исследованы принципы профессионального совершенствования с точки зрения ведущих ученых. Проанализированы такие принципы производственного персонала, как: политехнический принцип, принцип моделирования профессиональной деятельности в процессе обучения, принцип профессиональной мобильности, принцип модульности и т.д.

Ключевые слова: принцип обучения, партисипативность, синергия, непрерывное профессиональное обучение, совершенствование персонала.

Sushentzev A. O. Implementation of the principles of professional development of production personnel in Ukraine.

In the article the principles of professional development in terms of leading scientists are carried out. The principles of the production staff such as: polytechnic principle, the principle of modeling professional activities in the learning process, the principle of the professional mobility, the principle of modularity etc. are analyzed.

Key words: the principle of learning, participatory, synergy, continuous professional training, improvement of personnel. 
На сучасному етапі суспільного розвитку ефективне функціонування підприємства визначається насамперед основним виробничим ресурсом - людськими знаннями, інформацією і заснованою на них висококваліфікованою працею. Унаслідок запровадження високотехнологічного виробництва, нової техніки і матеріалів набуті знання, уміння та навички виробничого персоналу досить швидко старіють, тому здатність підприємства постійно вдосконалювати професійний рівень своїх робітників $\epsilon$ одним 3 найважливіших чинників забезпечення конкурентоспроможності підприємства на ринку, оновлення та зростання обсягів виробництва. Тож, вирішення завдань, пов'язаних з інтеграцією України до світового економічного простору, поширенням процесів глобалізації та конкуренції потребує підвищення ефективності навчання персоналу на виробництві.

У документах міжнародних організацій (ЮНЕСКО, Міжнародної організації праці, Ради Європи, Світового банку) основною рушійною силою економічного розвитку країн визнано людський капітал. У цьому контексті відновлення економічного зростання і становлення економіки знань полягає в інтенсивному формуванні системи професійного вдосконалення виробничого персоналу фірм, підприємств, організацій та ін.

Водночас професійне вдосконалення виробничого персоналу сприяє ефективному використанню трудового потенціалу особистості, підвищенню іiі соціальної та професійної мобільності, є засобом профілактики безробіття, відіграє значну роль у підготовці працівників для здійснення структурної й технологічної перебудови виробництва. Усе це позитивно впливає на збільшення обсягів випуску продукції, поліпшує результати фінансової діяльності організації.

Якщо основою стабільності соціально-економічного розвитку країни $\epsilon$ підготовка i вдосконалення виробничого потенціалу, то головним джерелом постачання такого персоналу є освіта. Підтвердженням цього є думка О. Грішнової, яка стверджує, що «освіта та професійна підготовка $є$ фундаментом людського розвитку і прогресу суспільства» [3, с. 101]. Досить переконливим прикладом є місце освітнього чинника в загальних якісних характеристиках працівника. Водночас варто звернути увагу на важливі зрушення відносно ролі і значення окремих компонентів цих якостей. На теперішній час ситуація склалася так, що професійна освіта стає визначальним чинником, що формує якісні характеристики робочої сили, i, як зауважує Н. Ничкало, «в усіх цивілізованих країнах здійснюється інтенсивний пошук нових моделей розвитку освіти, нетрадиційних підходів до їх упровадження на основі інформаційних і телекомунікаційних технологій» [4, с. 19]. Водночас, варто зауважити, що система підготовки все менше задовольняє потреби високотехнологічних виробництв, тому великі підприємства і організації розпочали нарощувати інвестицій в підготовку кадрів. Як свідчить аналіз практики підвищення кваліфікації виробничого персоналу, вона не встигає за змінами на виробництві (скорочення циклу виробництва та життя товарів, потреба в нових професіях i кваліфікаціях тощо) і зростаючими вимогами конкурентної боротьби на ринку праці.

Mema cmammi- здійснити теоретичний огляд принципів, на яких повинен грунтуватися весь процес професійного вдосконалення виробничого персоналу.

Задля обгрунтування основних принципів вдосконалення виробничого персоналу ми звернулися до аналізу здобутків вітчизняних та зарубіжних науковців. Методологічною основою дослідження стали філософські та культурологічні надбання, які віддзеркалюють зміни пріоритетів у системі цінностей усього людства.

Аналіз джерел науково-педагогічних розвідок показав, що дослідження 
підготовки кадрів на виробництві здійснювали Е. Кананикіна, M. Von Glinow, S. Kerr, D. Martin, D. Ravitch, J. Schriesheim, T. Wright та ін. У галузі порівняльної педагогіки досить глибоко досліджені реформаційні процеси систем освіти, підготовки кадрів та навчання безробітних у таких країнах, як: США (Н. Бідюк, В. Корнієнко, Т. Кошманова, В. Кудін, Л. Пуховська та ін.), Канади (М. Лещенко), Англії й Уельса (Н. Авшенюк), Китаю (Н. Пазюра), Польщі (А. Каплун), Туреччини (Т. Десятов) та ін. Питання методології професійної підготовки та підготовки робітничих кадрів на виробництві розглядалися у працях С. Батишева, Н. Ничкало, В. Супян та ін. Розв'язанню проблем підготовки кадрів на виробництві присвячені роботи О. Богачова, I. Заюкова, I. Миневріна, В. Савченка та ін. Проблеми підвищення кваліфікації робітників відображені в дослідженнях JI. Аферіної, А. Котюк, В. Панкова, В. Полуянова, О. Чубукової та ін.

3 точки зору класичної дидактики, принципи і правила залежать від мети i завдань професійного вдосконалення виробничого персоналу на конкретному етапі соціально-економічного прогресу. До прикладу, принципи наочності, міцності, послідовності й наступності були запропоновані й обгрунтовані ще Я. Коменським. Водночас процес професійного вдосконалення виробничого персоналу спирається на специфічні принципи професійного навчання, які перебувають у тісному взаємозв'язку із загальнодидактичними принципами, що відображають закономірності педагогічного процесу. Оскільки вдосконалення виробничого персоналу є керованим процесом, то під час підготовки повинні бути точно визначені завдання, що чітко відповідають цілям організації в цілому. Тож розглянемо специфічні принципи професійного навчання.

Політехнічний принцип передбачає оволодіння системою знань про наукові основи сучасного виробництва. На базі цих знань формуються загальнопрофесійні політехнічні (загальні засади класифікації техніки і технології; класифікація матеріалів, їх властивості і способи їх отримання; стандартизація, технічні вимірювання та оцінка якості продукції; організація праці тощо) та спеціальні знання (розкривають сутність конструкції обладнання, інструментів i пристосувань, застосовуваних для виконання окремих операцій та видів робіт, правила їх експлуатації, технологічних процесів тощо).

Принцип моделювання професійної діяльності в навчальному процесі передбачає виявлення типових професійних завдань і трансформацію їх у навчальновиробничі завдання. За допомогою моделювання можна отримати випереджальну інформацію для обгрунтування цілей, змісту, засобів і методів навчання, розробки професійно-кваліфікаційних характеристик, навчальних планів, програм i підручників. Завдання моделювання полягає у встановленні відповідності між вимогами, що пред'являються до професійної підготовки, i фактичним обсягом професійних знань і вмінь. У зв'язку з цим постає питання про прогнозування еталонних вимог до виробничого персоналу.

Принцип професійної мобільності передбачає здатність людини швидко освоювати технічні засоби, технологічні процеси і нові спеціальності, виховання потреби постійно підвищувати свою освіту та кваліфікацію. Мобільність, творчий характер праці залежать від широти кругозору, осмислення і розв'язання тих проблем, які людина має у своїй практиці, а також бачення і розуміння перспектив розвитку виробництва. «Тільки те навчання є хорошим, яке забігає вперед» (Л. Виготський). Тому необхідно враховувати не тільки те, що знає працівник сьогодні, а й те, що він зможе і зуміє дізнатися завтра. Мета навчання і полягає в тому, щоб, навчаючись, не тільки оволодіти професією, а й розвинути свій інтелект. 
Принцип модульності професійного навчання полягає в тому, що слухач самостійно може працювати за запропонованою йому індивідуальною навчальною програмою, яка включає в себе банк інформації і методичні рекомендації щодо досягнення поставлених дидактичних цілей. Використання принципу модульного навчання на практиці дозволяє будувати навчальний матеріал так, щоб розділи були відносно незалежними один від одного, а це дозволяє змінювати, доповнювати i перебудовувати навчальний матеріал, не порушуючи єдності змісту.

Принцип створення виробничо-навчального середовища передбачає, передовсія, створення навчально-матеріальної бази виробничого навчання і дидактичних засобів навчання, що відповідають технічним, технологічним, ергономічним, економічним, педагогічним, санітарно-гігієнічним, екологічним вимогам, а також вимогам безпеки праці та охорони здоров'я слухачів.

Принцип економічної доцільності визначає необхідність планування професійного вдосконалення виробничого персоналу з урахуванням вимог ринку праці [1, с. 117-119].

Варто зазначити, що підготовка персоналу $є$ важливим елементом у системі управління підприємства, організації як на колективному, так і на індивідуальному рівні. На колективному рівні підготовка є невід'ємною частиною розвитку організації, на індивідуальному - розвитку кар'єри кожного члена виробничого колективу.

В Україні професійне вдосконалення персоналу- це система заходів, спрямованих на підвищення кваліфікації працівників підприємства, воно має здійснюватися за такими напрямками: професійне навчання; підготовка і перепідготовка робітників, фахівців і керівників; підвищення кваліфікації; перекваліфікація виробничого персоналу промислових підприємств, освоєння нових професій і спеціальностей.

Метою професійного вдосконалення виробничого персоналу на виробництві має стати створення системи безперервної освіти персоналу на основі оптимального поєднання різних форм підготовки нових робітників, перепідготовки та навчання робітників інших професій, підвищення їх кваліфікації та рівня знань з урахуванням динамічних змін у техніці, технології, організації виробництва, у тісному взаємозв'язку з їх індивідуальним професійно-кваліфікаційним просуванням.

Під безперервним професійним навчанням працівників промислових підприємств розуміється цілеспрямований, пов'язаний зі стратегією підприємства загалом і здійснюваний протягом усієї трудової діяльності, процес безперервного підвищення кваліфікації персоналу на основі наявної у них професійної освіти в інтересах працівника, підприємства і суспільства в цілому. Професійне вдосконалення позитивно впливає на мотивацію персоналу до набуття і вдосконалення знань, умінь та навичок, сприяє його конкурентоздатності на ринку праці. Водночас створюються додаткові можливості для професійного зростання виробничого персоналу не тільки в межах цього підприємства, а й поза його межами. Зауважимо, що в умовах швидкого старіння знань це особливо важливо. Тому розроблення внутрішньофірмових програм вдосконалення виробничого персоналу дозволяє забезпечити ефективну роботу промислового підприємства.

Для організованого підвищення кваліфікації виробничого персоналу недостатньо розробити програми вдосконалення виробничого персоналу, необхідно, щоб процес підвищення кваліфікації спирався на певні закономірності, які, будучи сформульовані як нормативні положення, якими слід керуватися, стають принципами навчання.

Здійснений аналіз наукової літератури і практики свідчить, що дидактичні принципи (didactical principles) відображають основні положення теорії освіти й 
навчання, які розробляються в дидактиці. Вони, відображаючи якийсь один істотний аспект процесу навчання, стають підгрунтям для формування правил навчання [5, c. 110].

У системі підвищення кваліфікації виокремлюють принципи розроблення внутрішньофірмових програм вдосконалення виробничого персоналу, а саме:

- принцип цільового призначення (передбачає створення єдиної системи навчальних планів для компаній, організацій і підприємств в цілому; орієнтацію заходів, що включаються до програми підвищення кваліфікації кадрів, на реалізацію місії організації, на кінцеві результати діяльності);

- принцип випередження (означає, що розроблені в програмах підвищення кваліфікації заходи повинні забезпечувати випередження рівня професійнокваліфікаційної підготовки персоналу щодо термінів реалізації програм економічного, соціального і технічного розвитку підприємства);

- принцип взаємозв’язку (передбачає, щоб внутрішньофірмові програми професійного вдосконалення виробничого персоналу мали тісний взаємозв'язок 3 оцінкою, підбором, стимулюванням персоналу, а також з програмами технічного, технологічного, економічного та соціального розвитку);

- принцип зацікавленості (передбачає активне залучення управлінського персоналу різних рівнів у процес навчання їхніх підлеглих, а також матеріальну i моральну зацікавленість усіх суб'єктів внутрішньофірмової системи професійного вдосконалення виробничого персоналу);

- принцип варіантності, конкретності та адресності (передбачає використання різних форм і методів навчання (семінари, тренінги, круглі столи, навчання на робочому місці тощо), виходячи 3 категорії персоналу, поставлених завдань i тематики програм навчання та підвищення кваліфікації кадрів);

- принцип ресурсного забезпечення (передбачає створення фінансових, матеріально-технічних, кадрових, соціально-психологічних передумов задля забезпечення реалізації заходів внутрішньофірмових програм навчання та вдосконалення виробничого персоналу в необхідних обсягах і у визначені терміни).

У науковій літературі наявні різні підходи до систематизації принципів навчання, які відносяться до динамічно змінної категорії і під впливом досягнень сучасної дидактики постійно оновлюються. Поряд 3 класичними дидактичними принципами (науковості, систематичності й послідовності, доступності навчання, зв'язку навчання 3 життям, свідомості й активності, наочності в навчанні, міцності засвоєння знань, умінь і навичок, індивідуального підходу до слухачів, емоційності навчання та ін.) у процесі підвищення кваліфікації виробничого персоналу сформувалися специфічні та найбільш характерні принципи. Серед них науковці (3. Возгова) виокремлюють такі: принцип неперервності; принцип професійної мобільності виробничого персоналу; синергетичний принцип; принцип партисипативності; принцип рефлексивного управління вдосконаленням виробничого персоналу; принцип комунікативного партнерства i співробітництва; принцип фасилітації; принцип суб’ єктності; принцип елективності [2].

Розкриємо сутність кожного із названих принципів. Принцип неперервності $€$ ключовим принцип вдосконалення виробничого персоналу, він дозволяє розглядати процес вдосконалення виробничого персоналу як навчання впродовж життя. Принцип неперервності передбачає опору на самоосвіту, засвоєння професійних умінь i навичок, широке використання активних форм і методів навчання, підхід до навчання як процесу перетворення життєвого і професійного досвіду. 
Поява сучасного ринку праці вимагає від працівника конкурентоздатності i професійної мобільності. Тому досить важливим $\epsilon$ принцип професійної мобільності виробничого персоналу, який передбачає формування здатності персоналу до швидкого перенавчання, швидкої адаптації до зміни техніки, технології і навіть професії. 3 огляду на те, що процес професійного вдосконалення виробничого персоналу можна розглядати як синергію (співробітництво), взаємозалежність i особисту автономію, тому досить характерним для нього є синергетичний принцип, ключовими положеннями якого $\epsilon$ синергетичність процесу пізнання в системі професійного вдосконалення виробничого персоналу. Синергія (співробітництво), взаємозалежність i особиста автономія доповнюють педагогічні принципи, відображають ідеї освіти дорослих і зумовлюють успіх процесу пізнання; професійне вдосконалення виробничого персоналу розглядається 3 точки зору самоврядування, самоорганізації, саморозвитку у відкритих педагогічних системах.

На думку науковців (І. Касьянової, І. Кравченко, О. Нікітіної та ін.), невід’ємним складником процесу підвищення кваліфікації виробничого персоналу є принцип партисипативності, який передбачає не вплив, а суб'єкт-суб'єктну взаємодію між андрагогом-фасилітатором і слухачами. Андрагог-фасилітатор у своій діяльності повинен орієнтуватися на те, щоб було усвідомлене професійне співробітництво між слухачами в групі, а слухачі повинні брати активну участь в аналізі професійних навчально-пізнавальних завдань, плануванні спільних дій і оцінки та самооцінки. Аналіз наукової літератури свідчить, що термін «партисипативність» співвідноситься 3 такими поняттями, як «участь», «співучасть», «залученість», що зумовлено, ймовірно, особливостями перекладу з англійської і прагненням знайти більш точний аналог в українській мові цьому терміну [6, с. 49]. Водночас окремі автори (W. Deming, O. Irwin, P. Peterson) розрізняють ці поняття, прагнучи надати партисипативності семантичні відтінки, більш широкий або вужчий смисл.

Досить важливим на сучасному етапі розвитку системи підвищення кваліфікації $\epsilon$ забезпечення реалізації принципу рефлексивного управління вдосконаленням виробничого персоналу, а, отже, і забезпечення системної рефлексії професійного досвіду кожного слухача курсів підвищення кваліфікації. Активне залучення слухачів до діяльності, створення передумов самоорганізації, саморозвитку особистості кожного слухача курсів підвищення кваліфікації неможливе без урахування принципу фасилітації, який науковці (Е. Зеєр, К Роджерс, В. Сластьонін та ін.) називають ефективним принципом учіння. Стрижнева ідея принципу полягає в опорі на творчий потенціал слухача, у його переконанні та прагненні до самоактуалізації та самореалізації.

У процесі підвищення кваліфікації реалізується принцип комунікативного партнерства i співробітництва, який припускає розвиток відносин довіри, взаємодопомоги, взаємної відповідальності слухачів і андрагога-фасилітатора, а також розвиток поваги, довіри до особистості слухача 3 наданням йому можливості для вияву самостійності, ініціативи та індивідуальної відповідальності за результат. Зауважимо, що слухачі відчувають необхідність одне в одному, мають можливість вільно спілкуватися, висловлювати й акумулювати ідеї. Андрагог-фасилітатор визначає роль кожного члена групи, цілеспрямовує слухачів, заохочує і стимулює.

3 огляду на те, що дорослі слухачі курсів підвищення кваліфікації персоналу $є$ рівноправними суб'єктами процесу навчання, урахування принципу суб'єктності передбачає надання головної ролі у процесі підвищення кваліфікації самому слухачеві. Суб'єктність слухача курсів підвищення кваліфікації в широкому сенсі уявляється як синтез і трансформація суб'єктних властивостей особистості у 
професійно значущі особистісні якості.

Забезпечення можливості вибору індивідуальної траєкторії професійного самостановления здійснюється 3 урахуванням принципу елективності, що означає надання слухачеві свободи вибору цілей, змісту, форм, методів, джерел, засобів, термінів, часу, місця навчання, оцінювання результатів навчання тощо. Водночас цей принцип передбачає створення системи багаторівневої підготовки персоналу, урахування індивідуальних особливостей слухачів і надання кожному можливості максимального розкриття здібностей для отримання відповідного цим здібностям рівня професійної компетентності.

На наш погляд, педагогічно доцільними, ефективними для перспективного розвитку системи вдосконалення виробничого персоналу $\epsilon$ принципи, що відображають специфіку контингенту слухачів та особливості організації навчального процесу з професійного вдосконалення виробничого персоналу, зокрема: принцип системного підходу, що уможливлює взаємозв'язок, взаємодію окремих структурних компонентів системи вдосконалення виробничого персоналу; принцип гнучкості, який спрямований на вільний вибір змісту, форм і методів навчання персоналу; принцип інтеграції, що уможливлює організацію процесу навчання з використанням здобутків вітчизняних та зарубіжних науковців i практиків; принцип особистої спрямованості, що надає пріоритет особистісно орієнтованому навчанню, передбачає розвиток цілісної сукупності якостей особистості, яка охоплює суспільно необхідні знання, уміння, навички, риси характеру й інші ділові якості та забезпечує успішність практичної діяльності випускників освітніх установ [7, с. 7-13].

Отже, обгрунтована система принципів професійного вдосконалення виробничого персоналу свідчить, що всі принципи між собою тісно взаємопов'язані, зумовлюють один одного і сприяють підвищенню рівня професійного вдосконалення виробничого персоналу у процесі безперервного підвищення кваліфікації. Професійне вдосконалення виробничого персоналу 3 використанням обгрунтованих нами принципів організації навчального процесу характеризується складною структурною функціональністю, що i дозволило виокремити пріоритетні принципи, що сприятимуть розвитку системи вдосконалення виробничого персоналу.

\section{Література}

1. Профессиональная педагогика : [учебник] / Под ред. С. Я.Батышева, А. М. Новикова. - [3-е изд., перераб.]. - М. : Профессион. образов., 2010. - 456 с. 2. Возгова 3. В. Принципы непрерывного повышения квалификации научнопедагогических работников [Электронный ресурс] / 3. В. Возгова // Современные проблемы науки и образования. - 2011. - № 3.- Режим доступа : http://www.scienceeducation.ru/pdf/2011/3/ 10.pdf. - Заголовок с экрана. 3. Грішнова О. А. Людський капітал : формування в системі освіти і професійної підготовки / О. А. Грішнова. - К. : Знання, КОО, 2001. - 254 с. 4. Ничкало Н. Г. Трансформація професійно-технічної освіти України : [монографія]/ Н. Г. Ничкало. - К. : Пед. думка, 2008. - 200 с. 5. Фіцула М. М. Педагогіка / М. М. Фіцула. - К. : Академвидав, 2003. - 528 с. 6. Никитина Е. Ю. Теоретико-методическая основа формирования речевого этикета младших школьников / Елена Юрьевна Никитина, Зырянова Екатерина Алексеевна // Вестник ЧГПУ. - 2009. - № 12. - С. 43-53. 7. Селевко Г. К. Современные образовательные технологии / Г. К. Селевко. - М. : Нар. образов., 1998. - 408 с. 